\title{
Covid-19 Knowledge and Perceptions Among Dental Specialists: A Cross-Sectional Online Questionnaire Survey
}

\author{
Sami Aldhuwayhi ${ }^{1}$ \\ Sreekanth Kumar Mallineni $\mathbb{D}^{2-4}$ \\ Srinivasulu Sakhamuri $\left.{ }^{5}\right)^{5}$ \\ Amar Ashok Thakare' \\ Sahana Mallineni ${ }^{6}$ \\ Rishitha Sajja $^{7}$ \\ Mallika Sethi ${ }^{8}$ \\ Venkatesh Nettam ${ }^{9}$ \\ Azher Mohiuddin Mohammad ${ }^{10}$ \\ 'Department Prosthodontics, College of \\ Dentistry, Majmaah University, Al-majmaah, \\ I 1952, Saudi Arabia; ${ }^{2}$ Department of \\ Preventive Dental Sciences, College of \\ Dentistry, Majmaah University, Al-majmaah, \\ I 1952, Saudi Arabia; ${ }^{3}$ Department of \\ Pediatric and Preventive Dentistry, Narayana \\ Dental College and Hospital, Nellore, \\ Andhra Pradesh, India; ${ }^{4}$ Department of \\ Pediatric and Preventive Dentistry, Saveetha \\ Dental College and Hospitals, Saveetha \\ Institute of Medical and Technical Sciences, \\ Chennai, Tamil Nadu, India; ${ }^{5}$ Department of \\ Conservative Dentistry \& Endodontics, \\ Narayana Dental College and Hospital,, \\ Nellore, Andhra Pradesh, India; \\ ${ }^{6}$ Department of Periodontology, Krishna \\ Institute of Medical Sciences, Nellore, AP, \\ India; ${ }^{7}$ Data Manager, Bristol Myers Squibb, \\ New Brunswick, NJ, USA; ${ }^{8}$ Department of \\ Periodontology, ITS Dental College, \\ Muradnagar, Ghaziabad, Uttar Pradesh, India; \\ ${ }^{9}$ Department of Orthodontics, Narayana \\ Dental College and Hospital, Nellore, \\ Andhra Pradesh, India; ${ }^{10}$ Oral Maxillofacial \\ Surgery, Military Hospital, Riyadh, Saudi \\ Arabia
}

Correspondence: Sreekanth Kumar Mallineni

Pediatric Dentistry, Department of

Preventive Dental Science, College of

Dentistry, Majmaah University,

AlMajmaah, I1952, Saudi Arabia

Tel +966-50778016I

Email s.mallineni@mu.edu.sa
Background: The recent outbreak of coronavirus (COVID-19) caused a significant impact on dentistry. It is imperative to have sufficient knowledge of COVID-19 to manage patients in the dental operatory.

Aim: To assess the knowledge and perceptions of dentists from different specialities about COVID-19 disease.

Settings and Design: Cross-sectional online survey.

Materials and Methods: This study used a descriptive cross-sectional study design with a self-administered questionnaire. The questionnaire included three sets of 23 questions [Demographic-4; Source of information-1; Knowledge-10 and Perceptions-8]. The comparison of mean scores of knowledge and perceptions were interpreted based on the occupation of dental specialists.

Statistical Analysis Used: The association between demographic variables and dental specialists' knowledge and perception scores was carried out using SPSS (Version IBM 21.0, NY, USA).

Results: A total of 429 dentists from various specialties participated in the present study. The study had obtained a overall good knowledge score $(92.7 \%)$ with a mean value of $8.86+$ 0.22 , and a perception score $(70.7 \%)$ with a mean value of $5.4+0.3$. The present study reports a statistically significant difference between age $(\mathrm{p}=0.03)$ and knowledge source $(\mathrm{p}<0.05)$. The multi variate regression analysis showed that dentists' specialty had no significant effect on knowledge and perception.

Conclusion: The study reports sufficient knowledge and perception scores. Oral maxillofacial surgeons showed higher knowledge scores, while prosthodontics and periodontics achieved good mean scores for perception on COVID-19. Social media and health authorities played an equally important role in the overall knowledge of the source of information related to COVID-19.

Keywords: COVID-19, dentists, infection, questionnaire, dentistry

\section{Introduction}

The healthcare profession significantly impacted the current COVID-19 pandemic outbreak due to the transmission of the COVID-19 virus from positive patients. The COVID-19 virus is predominantly known to affect the respiratory system of the infected person. The incubation period is from 1-14 days, and mainly 3-7 days is the most infectious period. ${ }^{1}$ There is a significant threat to the dental profession as most dental treatments are aerosol-generating procedures (AGPs), and droplet spread is the 
predominant mode of transmission of the COVID-19 virus. Hence, the medical professions, especially dentists, are at high risk of transmission of this disease. There are higher chances of contamination of the dental operatory with infectious viral load from saliva, blood, and aerosols. ${ }^{2}$ The dental operatory and waiting room should have adequate ventilation. The coronavirus is reported to be viable in the air for $3 \mathrm{hrs}$ while $5.6 \mathrm{hrs}$ on stainless steel and $6.8 \mathrm{hrs}$ on plastic surfaces. ${ }^{3}$ Dentists are recommended to consider every patient as COVID-19 positive and expected to limit the treatments to emergency procedures. After completing the dental treatments, it is imperative to disinfect dental operatory to avoid transmitting infectious diseases adequately. ${ }^{4}$

Various health authorities such as the Centers for Disease Control and Prevention (CDC), American Dental Association (ADA), and the World Health Organization (WHO) have proposed guidelines for infection control and the safety of dentists and healthcare personnel. Developing protocols for infection control and usage of personal protection equipment (PPE) have been the primary focus. Dentists' can use various strategies such as rubber dam isolation, anti-retraction devices, and pre-procedure antimicrobial mouth rinse to reduce viral load in saliva for maximum safety and protection of dental staff and patients. Dentists' are expected to be familiar with the COVID-19 disease and the guidelines for treating patients in the operatory. ${ }^{5,6} \mathrm{~A}$ well-designed questionnaire is an excellent tool to understand dentists' knowledge and perceptions. $^{7-10}$ The present study aimed to assess dentists' knowledge and perceptions (faculty and private practitioners) from different specialties about the COVID-19 disease, mode of transmission, infection control measures, and their significant fears and concerns.

\section{Materials and Methods}

The study was conducted in full accordance with the World Medical Association Declaration of Helsinki and approved by the Ethics Committee of Majmaah University, Majmaah, Saudi Arabia (MUREC.July.22/ COM-2020/36-

2 ). The present study used a descriptive-analytical survey of the cross-sectional design. The participating dentists' were informed about the purpose of the study and how to answer the questionnaire. The present study was designed to assess the current pandemic COVID-19 among the dental specialists' knowledge and perceptions. The present study used a questionnaire consisting of various questions and multiple choices. A pilot study was carried out to validate the content and reliability of the questionnaire. It was a collaborative study (College of Dentistry, Majmaah University, KSA and Narayana Dental College and Hospital, Nellore, India), and data analysis was carried out across the dental specialities. Two investigators (MSK from KSA and SS from NDCH) have been involved in developing the questionnaire and in data collection. A convenience and snowball sampling technique was used for the study. The questionnaire was administered via an electronic Google form and was sent online (Whatsapp and email) from 15.07.2020 to 31.08.2020. The questionnaire (Appendix 1) included three sets of 23 questions [Demographic-4; Source of information-1; Knowledge-10 and Perceptions-8]. A welcome message was sent along with detailed study information to the participant to request to provide their consent. Participation in the study is voluntary and all the participants were asked to review participant information on welcome message and mark consent prior to participation in the survey to confirm their agreement to participate in this research study. Upon all participating dentists explicit willful consent and were recruited from faculty, and private practitioners belong to various specialties from India involved in the study. Undergraduates, postgraduates, general dentists, other allied health care professionals, dental specialists from other than India were excluded from the study. The study eliminated the questionnaires which had unanswered questions. All the participants were divided into groups based on the specialty [oral maxillofacial surgery, oral medicine, oral pathology, public health, conservative and endodontics, orthodontics, prosthodontics, periodontics, and pedodontics]. Each response was scored as "1" (positive) and " 0 " (negative), with scores ranging from 1 to 10 for knowledge and 1 to 8 for perceptions. The participants' perceptions were classified as good (>median) or poor (score $\leq$ median). Three options were considered to collect data related to the source of information on COVID-19 disease (1.Social media include WhatsApp, YouTube, Telegram, Facebook, Twitter, Snapchat, etc.; 2. Health authorities include WHO, CDC, ADA, university authorities, local and international societies; and 3. Both).

\section{Statistical Analysis}

The present study compared the data based on the occupation of dental specialists. Analysis of the data was performed using descriptive and chi-square statistics. The association between demographic variables and the dental specialists' knowledge scores was performed using multivariate linear regression analysis. A Chi-square test was 
used to know the association between study variables and perception questions. One-way ANOVA for multi-comparisons and Bonferroni coefficient tests to evaluate the correlation between knowledge and perceptions. The scores were expressed as mean value \pm standard deviation. All the statistical analysis was performed using IBM Corp. (Released in 2012. IBM SPSS Statistics for Windows, Version 21.0. Armonk, NY: IBM Corp.) with a 95\% confidence level where $\mathrm{p}<0.05$.

\section{Results}

Responses from 459 dentists from various specialties were available in the present study. Three hundred and ninetysix (194 males and 202 females) from various specialties were available for the analysis in the present study; an almost equal number of private practitioners (199) and faculty working in the university (197) have participated in the survey (Table 1). The present study questionnaires were completed from specialties, including oral maxillofacial surgery, oral medicine, oral pathology, public health, conservative dentistry and endodontics, orthodontics, prosthodontics, and periodontics, and pedodontics utilised for statistical analysis. Four hundred fifty-nine dental specialists participated in the survey, and 63 participants excluded from the final analysis. Among these 63 participants, 33 did not mention the specialty and significantly less participation from oral medicine (11), oral pathology (4), and public health dentistry (15).

The present study obtained an excellent overall knowledge score of $92.7 \%$, with a mean of $9.26 \pm 1.82$. Overall, $99.56 \%$ of participants from all dental specialties believed that coronavirus is a viral infection. A total of $80.71 \%$ of dental specialists believe that coronavirus is fatal; out of which $92.7 \%$ of oral surgeons and $74.2 \%$ of prosthodontists thought that it is fatal. The majority of specialist dentists had good knowledge (98.3\%, 98.9\%, 93.1\%, $98.7 \%$, and $97.3 \%$ ) for questions related to the mode of transmission by close contact with infected persons, the signs and symptoms of COVID-19 infection, incubation period around two weeks, the risk of COVID-19 for dentists and the impact of medical history (chronic diseases) as a risk factor in acquiring COVID-19 respectively (Table 2). A total of $90.6 \%$ of dentists believe that vaccine is not available in the market yet; only $83.9 \%$ of oral surgeons believe that COVID-19 can be prevented by hand sanitation, with the overall score being $91.58 \%$. Among the knowledge questions, using an N95 mask during COVID-19 pandemic achieved the least overall score $(78.7 \%)$. The mean scores achieved by each specialty were $9.04 \pm 1.43,9.47 \pm 0.87,9.35 \pm 0.96,9.19 \pm 1.2,9.32$ \pm 0.8 , and $9.2 \pm 0.8$ for conservative dentistry and endodontics, oral maxillofacial surgery, orthodontics, prosthodontics, periodontics, and pedodontics, respectively (Table 2). There was a vast disparity evident in high and low knowledge scores among dental specialists (Table 3). The present study reports a statistically significant difference between age $(p=0.03)$ and knowledge source $(p=0.00)$ (Table 4). Simultaneously, multivariate regression analysis showed that dentists' specialty had no significant effect on knowledge and perception.

The overall perception score was $70.7 \%$, with a mean value of $5.4 \pm 0.3$. About $66.53 \%$ of individuals are worried that one of their family members may get the COVID-19 virus, out of which highest were periodontists $(74.2 \%)$. Good scores were obtained for question-related preventive measures using standard and isolation precautions given by health authorities (92.13\%), and dentists must avail themselves of all information about the COVID-19 $(96.06 \%)$. The majority of dentists $(82.11 \%)$ believe that the prevalence of COVID-19 can be reduced by the active participation of health care workers in the hospital infection control program, with the least being oral surgeons (76.4\%). The least score was obtained $(77.35 \%)$ for interest in the intake of the COVID-19 vaccine when available, with the least being endodontists $(72.6 \%)$. A total of $77.88 \%$ of dentists believe that dental treatment should be provided to patients with COVID-19 positive, out of which $83 \%$ were orthodontists, and $70.6 \%$ were pedodontists (Table 5).

A significantly low score was obtained (39.83\%) for questions about the availability of information about COVID-19 in your professional society sufficient. Out of these, $51.6 \%$ were prosthodontists, and the least score being among periodontists (30.6\%). Out of all the perception questions, the least score $(34.76 \%)$ was obtained for the government institutions that can control the pandemic, which shows the concern among dentists about the government's available resources to manage the COVID-19 pandemic (Table 5). The source of information for the majority of dentists was the single source $(69.4 \%)$, and social media (34.1\%) and health authorities (38.9\%) played an equally important role in the overall knowledge and perceptions of dentists, around $27 \%$ of dentists relied on both the sources for information related to COVID-19 (Figure 1). 
Table I Socio-Demographic Characteristics of the Dental Specialists Who Participated in the Study

\begin{tabular}{|c|c|c|c|c|c|c|c|}
\hline Characteristics & $\begin{array}{l}\text { Conservative } \\
\text { dentistry and } \\
\text { Endodontics }\end{array}$ & $\begin{array}{c}\text { Oral } \\
\text { maxillo- } \\
\text { facial } \\
\text { surgery }\end{array}$ & Periodontics & Prosthodontics & Pedodontics & Orthodontics & Total \\
\hline \multicolumn{8}{|c|}{ Gender } \\
\hline Male & 32 & 32 & 28 & 34 & 44 & 24 & 194 \\
\hline Female & 30 & 23 & 34 & 28 & 58 & 29 & 202 \\
\hline Total & 62 & 55 & 62 & 62 & 102 & 53 & 396 \\
\hline \multicolumn{8}{|c|}{ Age (Years) } \\
\hline$\leq 30$ & 23 & 23 & 29 & 26 & 47 & 28 & 176 \\
\hline $3 I-35$ & 22 & 16 & 19 & 19 & 29 & 12 & 117 \\
\hline $36-40$ & 7 & 7 & 5 & 11 & 6 & 2 & 38 \\
\hline $4 I-45$ & 5 & 5 & I & 3 & 9 & 7 & 31 \\
\hline $46-50$ & I & 1 & 5 & I & 7 & 4 & 19 \\
\hline More than 50 & 4 & 3 & 3 & I & 4 & 0 & 15 \\
\hline Total & 62 & 55 & 62 & 62 & 102 & 53 & 396 \\
\hline
\end{tabular}

The overall mean knowledge score was $9.26 \pm 1.82$, and among the dental specialists, oral maxillofacial surgeons achieved the highest mean scores $(9.5 \pm 0.87)$. In contrast, specialists who belong to conservative dentistry and endodontics achieved lower mean scores $(9.04 \pm 1.43)$, as summarised in Table 3. Prosthodontists (5.85 \pm 1.34$)$ and periodontists $(5.85 \pm 1.26)$ achieved a higher mean score, and oral maxillofacial surgeons achieved a lesser score $(5.4 \pm 1.69)$ with overall mean scores of $5.4 \pm 0.39$ in case perceptions on COVID-19 (Table 3). Both knowledge and perceptions mean scores showed no statistical significance among the specialties.

The overall mean knowledge scores showed statistical significance with age and source of information $(\mathrm{P}<0.05)$, while the dental specialty does not offer any significance $(\mathrm{P}>0.05)$. Perception mean scores were not influenced by age, department, and source of information $(\mathrm{P}>0.05)$, as summarised in Table 4. The dental specialists who participated in the study showed high median scores for both knowledge (8) and perceptions (6) of the COVID-19 disease, respectively (Table 5). Participants achieved minimum knowledge scores in specialities of pedodontics (2), conservative dentistry, and endodontics (3), while the maximum score 10 for all the other departments. Participants achieved the minimum perception scores in the specialities of conservative dentistry and endodontics $(0)$, pedodontists $(0)$, and oral maxillofacial surgeons $(0)$, while maximum score 8 for all the other departments (Table 3 ). The mean and median values of overall scores based on the departments were summarised in Table 6 . Almost all the specialists achieved the same mean median regarding knowledge and perceptions irrespective of the specialty (Table 6).

\section{Discussion}

The present study was carried out among the dental specialist from various dental specialities when the COVID19 pandemic was reaching its highest peak among different specialities of dentistry and is one of the studies with a sample size of 396 dentists. This study investigates dental specialists' knowledge, and perceptions about COVID-19 and evaluates their primary information source. A total of 202 females and 194 males participated in this study from different dental specialties. Earlier studies from Italy $(349)^{11}$ and Jordan (368) ${ }^{12}$ reported with almost equal participants. The present study obtained an overall knowledge score of $92.7 \%$, with a mean of $8.86 \pm 0.22$. In contrast, Gambhir and co-workers, ${ }^{13}$ in a survey performed among Indian dentists, have reported a high knowledge score in only 65 dentists $(30.2 \%)$, and around 
Table 2 Knowledge Scores on COVID-19 Among Dental Specialists

\begin{tabular}{|c|c|c|c|c|c|c|c|}
\hline Knowledge & $\begin{array}{l}\text { Conservative } \\
\text { Dentistry and } \\
\text { Endodontics }\end{array}$ & $\begin{array}{l}\text { Oral } \\
\text { Maxillo- } \\
\text { Facial } \\
\text { Surgery }\end{array}$ & Periodontics & Prosthodontics & Pedodontics & Orthodontics & $\begin{array}{l}\text { Overal } \\
\text { Scores }\end{array}$ \\
\hline $\begin{array}{l}\text { Do you know that COVID- } \\
19 \text { is a viral infection? }\end{array}$ & $98 \%$ & $100 \%$ & $100 \%$ & $100 \%$ & $99 \%$ & $100 \%$ & $100 \%$ \\
\hline $\begin{array}{l}\text { Do you know that COVID- } \\
\text { I9 is fatal? }\end{array}$ & $81 \%$ & $93 \%$ & $81 \%$ & $74 \%$ & $75 \%$ & $82 \%$ & $81 \%$ \\
\hline $\begin{array}{l}\text { Do you know that COVID- } \\
\text { I9 is transmitted by close } \\
\text { contact with an infected } \\
\text { person? }\end{array}$ & $95 \%$ & $98 \%$ & $100 \%$ & $98 \%$ & $98 \%$ & $100 \%$ & $98 \%$ \\
\hline $\begin{array}{l}\text { Do you know that fever, } \\
\text { cough, and shortness of } \\
\text { breath are symptoms of } \\
\text { COVID-19? }\end{array}$ & $98 \%$ & $98 \%$ & $100 \%$ & $100 \%$ & $99 \%$ & $98 \%$ & $99 \%$ \\
\hline $\begin{array}{l}\text { Do you know that the } \\
\text { incubation period is } \\
\text { COVID-19 is } 2 \text { weeks? }\end{array}$ & $90 \%$ & $91 \%$ & $94 \%$ & $92 \%$ & $96 \%$ & $96 \%$ & $93 \%$ \\
\hline $\begin{array}{l}\text { Do you think the vaccine is } \\
\text { available in markets? }\end{array}$ & $94 \%$ & $91 \%$ & $87 \%$ & $90 \%$ & $93 \%$ & $89 \%$ & $91 \%$ \\
\hline $\begin{array}{l}\text { Do you think washing hands } \\
\text { with soap and water or } \\
\text { sanitizer can help prevent } \\
\text { COVID-I } 9 \text { transmission? }\end{array}$ & $84 \%$ & $91 \%$ & $95 \%$ & $97 \%$ & $90 \%$ & $93 \%$ & $92 \%$ \\
\hline $\begin{array}{l}\text { Do you know dentists are at } \\
\text { a higher risk of COVID-I9? }\end{array}$ & $97 \%$ & $100 \%$ & $98 \%$ & $100 \%$ & $99 \%$ & $98 \%$ & $99 \%$ \\
\hline $\begin{array}{l}\text { Do you think patients with } \\
\text { underlying chronic diseases } \\
\text { are at a higher risk of } \\
\text { COVID-I9? }\end{array}$ & $97 \%$ & $95 \%$ & $100 \%$ & $98 \%$ & $96 \%$ & $98 \%$ & $97 \%$ \\
\hline $\begin{array}{l}\text { Do you know that the use } \\
\text { of N-95 can help in avoiding } \\
\text { COVID-19? }\end{array}$ & $71 \%$ & $91 \%$ & $77 \%$ & $76 \%$ & $75 \%$ & $83 \%$ & $79 \%$ \\
\hline
\end{tabular}

82 dentists reported a lesser knowledge mean score of 6.56 \pm 2.54 . In the present study, a knowledge score of $62.1 \%$ was achieved related to COVID-19, with the periodontist $(54.8 \%)$ being the least. The low score might be due to the lack of established guidelines from health authorities and concern among the dentists due to ever-increasing mortality rates during this pandemic outbreak. Only $78.7 \%$ of dentists believe that usage of the N95 mask can prevent the transmission of COVID-19, out of which oral surgeons ranked the least $(71 \%)$. A low score achieved in the present study may be due to the relative unavailability of the
N95 mask for usage and comparatively higher cost. Cagetti and co-workers ${ }^{14}$ from Italy reported a similar score of $74.5 \%$ with a surgical mask with a sample size of 3599 . Ahmed and co-workers ${ }^{15}$ reported a study that included dentists from 30 countries and reported a significantly low score ( $9 \%$ ) to use the N-95 mask among general and specialty practitioners.

Similarly, significantly low scores (12.36\% and 18.4\%) were reported by two other studies by Duruk and coworkers $^{16}$ and Putrino and co-workers. ${ }^{17}$ Around $90.6 \%$ of dentists believe that vaccine is not available yet in the 


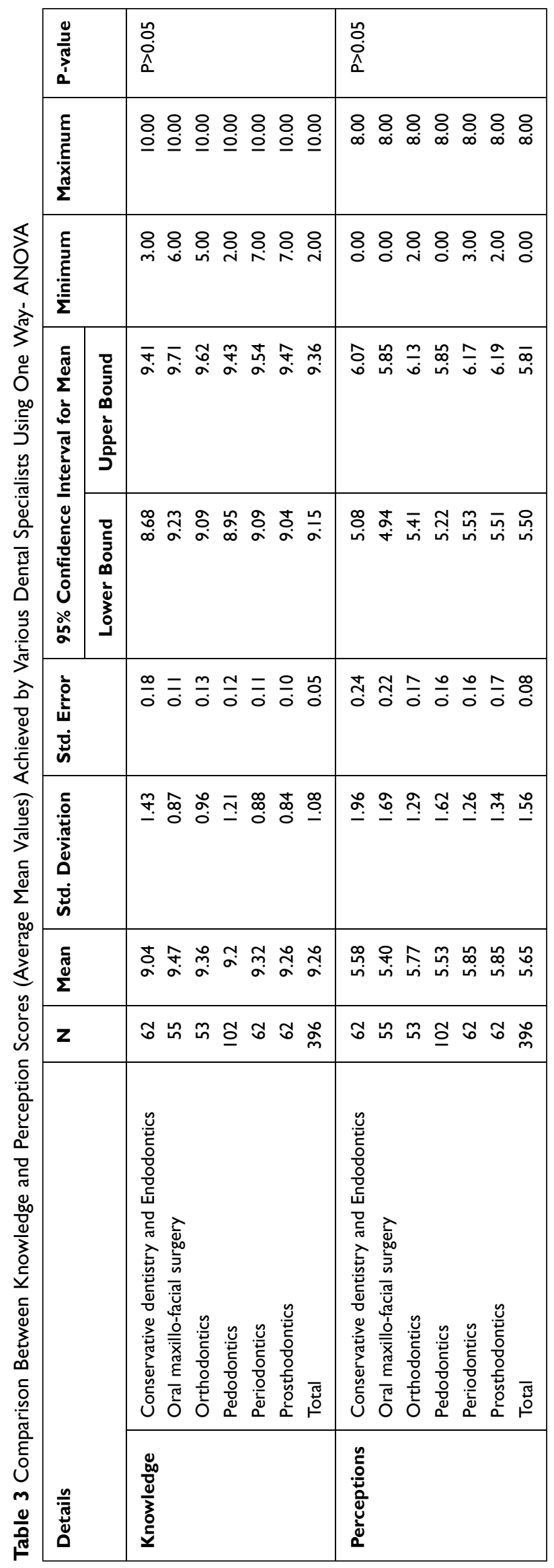

market. Contrarily, Gambhir and co-workers ${ }^{13}$ reported that $42 \%$ of subjects had adequate knowledge regarding vaccines to prevent COVID-19. Zhong and co-workers ${ }^{18}$ stated that $94 \%$ of dentists have sufficient knowledge about vaccine availability in a study of sample size 6919 dentists in China, while Kamate and co-workers ${ }^{19}$ described a score of $68.1 \%$ regarding knowledge on a vaccine from their multi-national study. In this study, dentists had adequate knowledge that repeated handwashing with soap and sanitizers (91.5\%) can help prevent infection transmission and these findings were in agreement with prior studies. ${ }^{10-12,16}$

The present study obtained an overall perception score of $70.7 \%$ with a mean value of $5.4 \pm 0.3$. Only $77.3 \%$ of dental specialists believed that vaccine would prevent COVID-19 disease; among them, endodontists scored the least $(72.6 \%)$. The uncertainty might be due to the unavailability of the vaccine in the market. Around $92.13 \%$ believed that usage of standard guidelines recommended by health authorities could significantly reduce transmission risk. Khader and co-workers ${ }^{12}$ found that $92.9 \%$ of dentists in Jordan were willing to wear personal protective equipment such as masks, gloves, and goggles recommended by health authorities. The fear of transmission of the COVID-19 was observed in $66.5 \%$ of dentists who participated in the present study. Five prior surveys by Cagetti and co-workers ${ }^{14}$ (80.3\%), Kinnariwala and coworkers $^{20}(97 \%)$, Ahmed and co-workers (92\%), Martina and co-workers ${ }^{15}(88 \%)$, and Putrino and co-workers ${ }^{19}$ $(87.5 \%)$ significantly higher scores. However, the present study was conducted among dentists' from various specialities. According to Duruk and co-workers, ${ }^{16}$ over $95 \%$ of Turkey's dentists were more concerned that their families might get infected as dentists are more prone to carry the infection from the aerosols in the dental operatory. Compared to other studies, the present study's low score might be due to the availability of standard guidelines to prevent transmission of the COVID-19 infection, and dentists have adequate knowledge to limit disease transmission. Around $82.11 \%$ of dentists agree that participation as a health care worker in a hospital infection control program can reduce the transmission of the COVID-19 virus. Questions related to the availability of information in the professional society $(39.8 \%)$ and government institutions' potentiality to handle this pandemic $(34.7 \%)$ obtained significantly lesser scores. The results show the governments' necessity to act successfully to limit infection transmission and provide financial aid for organizations facing a crisis 
Table 4 Association Between Demographic Variables and the Dental Specialist's Knowledge and Perception Scores Using the Multivariate Linear Regression Analysis

\begin{tabular}{|c|c|c|c|c|c|c|c|c|}
\hline \multirow{2}{*}{\multicolumn{2}{|c|}{ Details }} & \multicolumn{2}{|c|}{$\begin{array}{l}\text { Unstandardized } \\
\text { Coefficients }\end{array}$} & \multirow{2}{*}{$\begin{array}{c}\text { Standardized Coefficients } \\
\text { Beta }\end{array}$} & \multirow[t]{2}{*}{$\mathbf{t}$} & \multirow[t]{2}{*}{ P-value } & \multicolumn{2}{|c|}{$\begin{array}{l}\text { 95.0\% Confidence Interval for } \\
\text { B }\end{array}$} \\
\hline & & B & Std. Error & & & & Lower Bound & Upper Bound \\
\hline \multirow[t]{4}{*}{ Knowledge } & (Constant) & 8.87 & 0.23 & & 38.76 & 0.00 & 8.42 & 9.32 \\
\hline & Age (Years) & -0.04 & 0.02 & -0.10 & -2.11 & 0.03 & -0.08 & -0.01 \\
\hline & Department & 0.01 & 0.03 & 0.02 & 0.46 & 0.65 & -0.05 & 0.08 \\
\hline & Source & 0.41 & 0.12 & 0.18 & 3.57 & 0.00 & 0.19 & 0.64 \\
\hline \multicolumn{9}{|c|}{ a. Dependent Variable: knowledge score } \\
\hline \multirow[t]{4}{*}{ Perceptions } & (Constant) & 5.45 & 0.37 & & 16.22 & 0.00 & 4.79 & 6.11 \\
\hline & Age (Years) & -0.03 & 0.03 & -0.05 & -0.99 & 0.32 & -0.09 & 0.03 \\
\hline & Department & 0.07 & 0.05 & 0.07 & 1.39 & 0.16 & -0.03 & 0.16 \\
\hline & Source & 0.08 & 0.17 & 0.05 & 0.49 & 0.62 & -0.25 & 0.42 \\
\hline
\end{tabular}

during this time..$^{21}$ The source of information for $69.4 \%$ of dentists was from a single source, and the rest $30 \%$ is from multiple sources. The knowledge score was observed to be dependent on the source of information. It was evident that the information on COVID-19 from the social media and health authorities successfully provided adequate knowledge to dentists in the present study.

A Pakistani study found a low mean knowledge score of $4.19 \pm 1.88 / 12$ and a positive attitude score of $12.24 \pm 3.23$ / 15 on COVID-19 among dentists. ${ }^{22}$ The present study, the overall mean knowledge, and perception scores were 9.26 $\pm 1.82 / 10$ and $5.4 \pm 0.3 / 9$, respectively. Pakistani study was clearly stated that the specialist of the dentists participated in their study. ${ }^{22}$ Putrino and co-workers ${ }^{18}$ conducted a study in Italy with general dentists (42\%) and specialist dentists (58\%), and authors have not revealed the knowledge and awareness scores for the individual specialty. The present study was performed among various dental specialists; hence the results were not comparable. The overall knowledge mean scores on COVID-19 showed statistical significance with age and source of information $(\mathrm{P}<0.05)$, while the dental specialty does not offer any statistical significance $(\mathrm{P}>0.05)$. Perception mean scores were not influenced by age, the department, and information source $(\mathrm{P}>0.05)$. The median for knowledge and perceptions were 8 and 6 , respectively. The dental specialists who participated in the study showed high median scores for both knowledge and perceptions of the COVID-19 disease. None of the studies published in the literature reported the influence of age factors, the source of information, and dental specialty on the knowledge and perceptions of COVID-19. ${ }^{1-18}$ The majority of the dental specialists achieved a maximum score for knowledge (10) and perceptions (8) in the present study. The good scores obtained are due to adequate information from social media and health authorities focused on the COVID-19 globally. The authors opine that the health authorities around the successfully dealt with the pandemic outbreak of COVID-19. Overall, the study results demonstrate that dentists have an adequate basic understanding of COVID-19 disease transmission, fatality, and methods to prevent the same. However, there is a need for established guidelines from health authorities and more successful government strategies to ensure the dentists that the disease would be under control. ${ }^{23-28}$ Furthermore, a recent study from the United States stated that a new level of protective measures are required in the dental operatory, and updated operational guidance and policies are obligatory among oral health care professionals. ${ }^{27} \mathrm{~A}$ Italian study ${ }^{29}$ reported similar scores of knowledge (87\%) regarding COVID-19 and lower scores regarding perceptions (56\%) COVID-19. This study was conducted among the dental students hence the present study findings were not comparable. A few studies ${ }^{30-34}$ from various countries had have been reported on knowledge and perceptions regarding COVID-19 among dentists. No study was performed among the dental specialists. An Italian group ${ }^{35}$ of authors suggested that the COVID-19 might change the training approach in dentistry in coming years by necessity an innovative suggestion to avoid infection risk. A piece of holistic information about any 
Table 5 Perception Scores COVID-19 Among Dental Specialists

\begin{tabular}{|c|c|c|c|c|c|c|c|}
\hline Perceptions & $\begin{array}{l}\text { Conservative } \\
\text { Dentistry and } \\
\text { Endodontics }\end{array}$ & $\begin{array}{l}\text { Oral } \\
\text { Maxillo- } \\
\text { Facial } \\
\text { Surgery }\end{array}$ & Orthodontics & Pedodontics & Periodontics & Prosthodontics & $\begin{array}{l}\text { Overall } \\
\text { Scores }\end{array}$ \\
\hline $\begin{array}{l}\text { Are you worried one of } \\
\text { your family members may } \\
\text { get COVID-I9? }\end{array}$ & $65 \%$ & $58 \%$ & $68 \%$ & $67 \%$ & $74 \%$ & $68 \%$ & $67 \%$ \\
\hline $\begin{array}{l}\text { Transmission of COVID-19 } \\
\text { can be prevented using } \\
\text { standard and isolation } \\
\text { precautions given by WHO, } \\
\text { CDC, ADA, etc? }\end{array}$ & $90 \%$ & $89 \%$ & $96 \%$ & $90 \%$ & $94 \%$ & $94 \%$ & $92 \%$ \\
\hline $\begin{array}{l}\text { The prevalence of COVID- } \\
19 \text { can be reduced by the } \\
\text { active participation of health } \\
\text { care workers in the hospital } \\
\text { infection control program? }\end{array}$ & $84 \%$ & $76 \%$ & $81 \%$ & $80 \%$ & $92 \%$ & $79 \%$ & $82 \%$ \\
\hline $\begin{array}{l}\text { If a COVID-19 vaccine is } \\
\text { available, would you have it? }\end{array}$ & $73 \%$ & $75 \%$ & $79 \%$ & $77 \%$ & $86 \%$ & $76 \%$ & $78 \%$ \\
\hline $\begin{array}{l}\text { Do you think dental } \\
\text { treatment should be } \\
\text { provided to patients with } \\
\text { COVID-19 positive? }\end{array}$ & $74 \%$ & $78 \%$ & $83 \%$ & $71 \%$ & $79 \%$ & $82 \%$ & $78 \%$ \\
\hline $\begin{array}{l}\text { Dentists must avail } \\
\text { themselves of all } \\
\text { information about the } \\
\text { COVID-19? }\end{array}$ & $95 \%$ & $93 \%$ & $96 \%$ & $97 \%$ & $98 \%$ & $97 \%$ & $96 \%$ \\
\hline $\begin{array}{l}\text { Is the available information } \\
\text { about COVID-19 in your } \\
\text { professional society } \\
\text { sufficient? }\end{array}$ & $39 \%$ & $38 \%$ & $38 \%$ & $42 \%$ & $31 \%$ & $52 \%$ & $40 \%$ \\
\hline $\begin{array}{l}\text { Are the government } \\
\text { institutions able to control } \\
\text { the pandemic? }\end{array}$ & $39 \%$ & $33 \%$ & $36 \%$ & $30 \%$ & $32 \%$ & $39 \%$ & $35 \%$ \\
\hline
\end{tabular}

communicable disease is essential to prevent and control this transmission, especially susceptible. The authors ${ }^{35}$ also suggested blended learning in dental education. A recent multi-national study ${ }^{36}$ involving 2045 dental academicians from 26 countries found lower knowledge scores regarding the symptoms of COVID-19 than the diagnostic methods used for COVID-19. These findings are not compared to the present study because the present study objectives are knowledge and perception regarding COVID-19. The dentists from nine specialities have participated in the study, and among the study sample, the departments (oral pathology, oral medicine, and community dentistry) were excluded from the final analysis due to significantly less sample size. The study was performed in the Indian subcontinent, and all the participants participated from India. The study's limitations are a small sample size, and the research was conducted during the early stage of the COVID-19 pandemic outbreak. Only 429 participants from different specialities were participated in the present study, and the questionnaire was sent through social media; hence, the response rate was not sought. It is also considered a potential limitation. To the best of our knowledge, no 


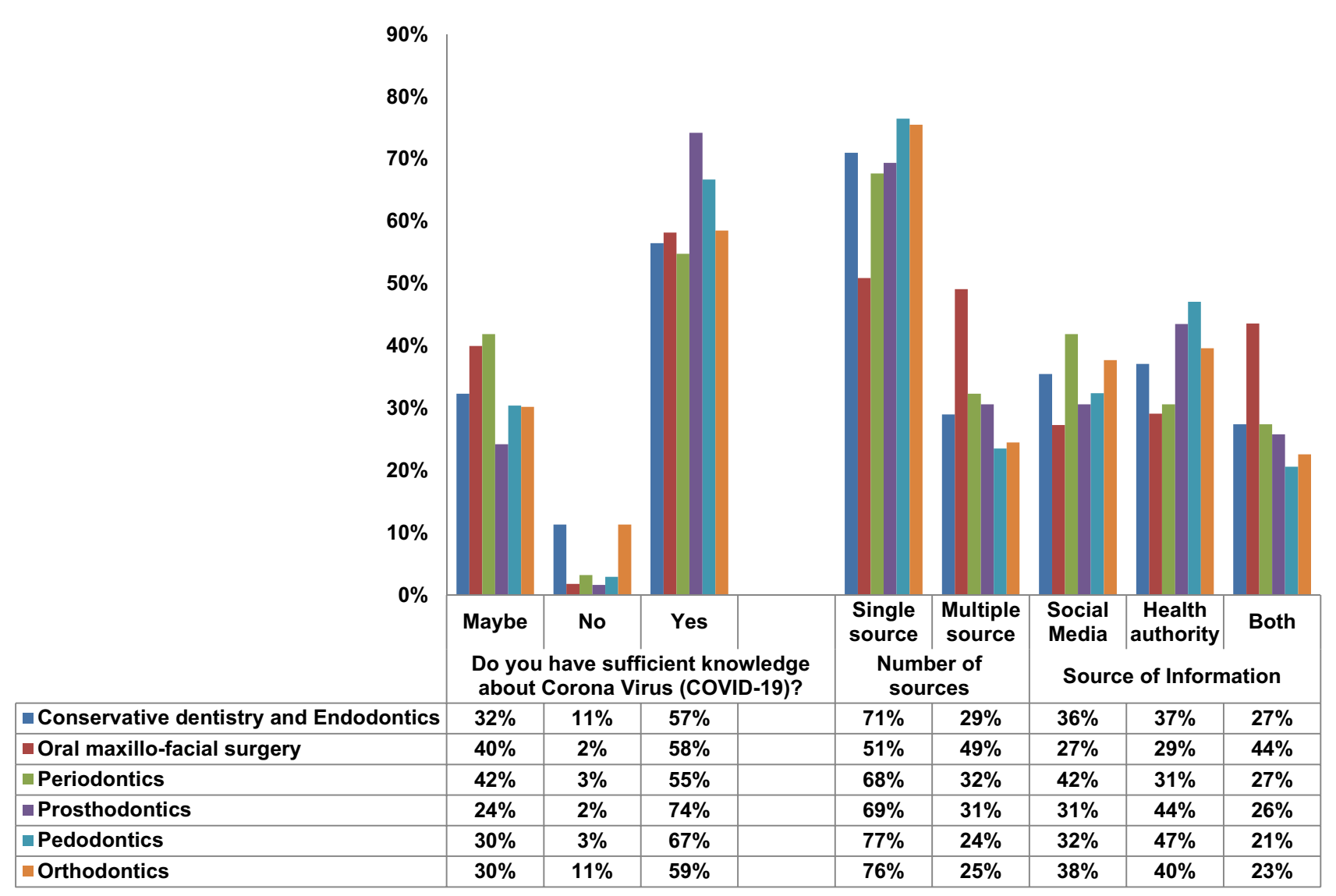

Figure I The details of the source of information utilized by dental specialists who participated in the study.

literature exists on the dental specialists' knowledge and perception scores on COVID-19. Despite these limitations, this study's findings may contribute to the existing literature by exploring the determinants of knowledge and perception regarding COVID-19 among dental specialists belonging to various specialities. Nonetheless, the study was the first of

Table 6 Knowledge and Perception Scores of the Participants Regarding Coronavirus Disease 2019

\begin{tabular}{|c|c|c|c|c|c|c|c|}
\hline Details & Details & $\begin{array}{l}\text { Conservative } \\
\text { Dentistry and } \\
\text { Endodontics }\end{array}$ & $\begin{array}{c}\text { Oral } \\
\text { Maxillo- } \\
\text { Facial } \\
\text { Surgery }\end{array}$ & Periodontics & Prosthodontics & Pedodontics & Orthodontics \\
\hline \multirow[t]{6}{*}{ Knowledge } & $\begin{array}{l}\text { Range of scores achieved } \\
\text { (maximum) }\end{array}$ & 10 & 10 & 10 & 10 & 10 & 10 \\
\hline & Minimum & 3 & 6 & 7 & 7 & 2 & 5 \\
\hline & Mean & 9.5 & 9.47 & 9.3 & 9.26 & 9.2 & 9.3 \\
\hline & Median (cut-off point) 8 & 9.5 & 10 & 10 & 9 & 10 & 10 \\
\hline & Good knowledge scores n (\%) & 77 & 87 & 85 & 84 & 82 & 87 \\
\hline & Poor knowledge scores n (\%) & 23 & 13 & 15 & 16 & 18 & 13 \\
\hline \multirow[t]{6}{*}{ Perceptions } & $\begin{array}{l}\text { Range of scores achieved } \\
\text { (maximum 8) }\end{array}$ & 8 & 8 & 8 & 8 & 8 & 8 \\
\hline & Minimum & 0 & 0 & 3 & 2 & 0 & 2 \\
\hline & Mean \pm SD & 5.58 & 5.4 & 5.8 & 5.8 & 5.5 & 5.7 \\
\hline & Median (cut-off point) 8 & 6 & 6 & 6 & 6 & 6 & 6 \\
\hline & Good knowledge scores n (\%) & 44 & 49 & 39 & 42 & 45 & 38 \\
\hline & Poor knowledge scores n (\%) & 56 & 51 & 61 & 58 & 55 & 62 \\
\hline
\end{tabular}


its kind to study knowledge and perceptions (attitude and awareness) among dental specialists.

The dental specialists' showed adequate knowledge of disease and preventive measures. There seems to be a gap in understanding the precautionary measures such as usage of N95 masks and vaccines, availability of information in a professional society, and regular updates from the government in successful control of the pandemic. Health authorities succeeded in promoting the COVID-19 and precautions to avoid the spread of the viral disease. Currently, COVID-19 disease is reaching a peak in various territories around the globe. The gap should be filled to make sure the dentist, auxiliaries, and their families are at low risk of transmitting the COVID-19 disease.

\section{Conclusion}

The present study reported an overall sufficient knowledge and perception scores, and dentists had an adequate understanding of COVID-19 disease and preventive measures. Oral maxillofacial surgeons showed higher knowledge scores among all the specialities, while prosthodontists and periodontists achieved good perception scores. The majority of dentists have used a single source for information (69.4\%), and social media (34.1\%) and health authorities $(38.9 \%)$ played an equally important role in the overall knowledge related to COVID-19.

\section{Acknowledgments}

The authors would like to thank all the participants who participated in the study.

The authors would like to thank Dr. Ajay Reginald, the Principal Narayana Dental College, and Hospital, Nellore, Andhra Pradesh, India.

The authors would like to thank the Deanship of Scientific Research at Majmaah University for supporting this work (R-2021-144).

\section{Author Contributions}

All authors made significant contributions to conception and design, acquisition of data, or analysis and interpretation of data; took part in preparing the manuscript or revision or proofreading it critically for important intellectual content; approved to submit to the Risk Management and Healthcare Policy; All the authors have given final approval of the version to be published; and agreed to be responsible for all aspects of the work.

\section{Disclosure}

All the authors declared no conflicts of interest.

\section{References}

1. Pereira LJ, Pereira CV, Murata RM, Pardi V, Pereira-Dourado SM. Biological and social aspects of Coronavirus Disease 2019 (COVID19) related to oral health. Braz Oral Res. 2020;34:e041. doi:10.1590/ 1807-3107bor-2020.vol34.0041

2. Mallineni SK, Innes NP, Raggio DP, Araujo MP, Robertson MD, Jayaraman J. Coronavirus disease (COVID-19): characteristics in children and considerations for dentists providing their care. Int $J$ Paediatr Dent. 2020;30(3):245-250. doi:10.1111/ipd.12653

3. van Doremalen N, Bushmaker T, Morris DH, et al. Aerosol and Surface Stability of SARS-CoV-2 as Compared with SARS-CoV-1. $N$ Engl $J$ Med. 2020;382(16):1564-1567. doi:10.1056/NEJMc2004973

4. Bhumireddy JC, Mallineni SK, Nuvvula S. Challenges and possible solutions in dental practice during and post COVID-19. Environ Sci Pollut Res. 2020;7:1-3.

5. Song Y, Son YJ, Oh D. Methodological Issues in Questionnaire Design. J Korean Acad Nurs. 2015;45(3):323-328. doi:10.4040/ jkan.2015.45.3.323

6. Srivastava KC, Shrivastava D, Sghaireen MG, et al. Knowledge, attitudes and practices regarding COVID-19 among dental health care professionals: a cross-sectional study in Saudi Arabia. $J$ Int Med Res. 2020;48(12):030006052097759. doi:10.1177/ 0300060520977593

7. Bordea IR, Candrea S, Sălăgean T, et al. Impact of COVID-19 pandemic on healthcare professionals and oral care operational services: a systemic review. Risk Manag Healthc Policy. 2021;14:453463. doi:10.2147/RMHP.S284557

8. Islam MS, Rahman KM, Sun Y, Qureshi M, Abdi I, Chughtai A. Current knowledge of COVID-19 and infection prevention and control strategies in healthcare settings: a global analysis. Infect Control Hosp Epidemiol. 2020;41(10):1196-1206. doi:10.1017/ice.2020.237

9. Lai X, Wang X, Yang Q, et al. Will healthcare workers improve infection prevention and control behaviors as COVID-19 risk emerges and increases, in China? Antimicrob Resist Infect Control. 2020;9(1):1-9. doi:10.1186/s13756-020-00746-1

10. Chughtai AA, Seale H, Islam MS, Owais M, Macintyre CR. Policies on the use of respiratory protection for hospital health workers to protect from coronavirus disease (COVID-19). Int J Nurs Stud. 2020;105:103567. doi:10.1016/j.ijnurstu.2020.103567

11. Martina S, Amato A, Rongo R, Caggiano M, Amato M. The Perception of COVID-19 among Italian Dentists: an Orthodontic Point of View. Int J Environ Res Public Health. 2020;17(12):4384. doi:10.3390/ijerph17124384

12. Khader Y, Al Nsour M, Al-Batayneh OB, et al. Dentists' awareness, perception, and attitude regarding COVID-19 and infection control: cross-sectional study among Jordanian dentists. JMIR Public Health Surveill. 2020;6(2):e18798. doi:10.2196/18798

13. Singh Gambhir R, Singh Dhaliwal J, Aggarwal A, Anand S, Anand V, Kaur Bhangu A. Covid-19: a survey on knowledge, awareness and hygiene practices among dental health professionals in an Indian scenario. Rocz Panstw Zakl Hig. 2020;71(2):223-229. doi:10.32394/ rpzh.2020.0115

14. Cagetti MG, Cairoli JL, Senna A, Campus G. COVID-19 outbreak in North Italy: an overview on dentistry. a questionnaire survey. Int $J$ Environ Res Public Health. 2020;17(11):3835. doi:10.3390/ ijerph17113835

15. Ahmed MA, Jouhar R, Ahmed N, et al. Fear and practice modifications among dentists to combat novel coronavirus disease (COVID19) outbreak. Int $J$ Environ Res Public Health. 2020;17(8):2821. doi:10.3390/ijerph17082821 
16. Duruk G, Gümüşboğa ZŞ, Çolak C. Investigation of Turkish dentists' clinical attitudes and behaviors towards the COVID-19 pandemic: a survey study. Braz Oral Res. 2020;34:e054. doi:10.1590/18073107bor-2020.vol34.0054

17. Putrino A, Raso M, Magazzino C, Galluccio G. Coronavirus (COVID-19) in Italy: knowledge, management of patients and clinical experience of Italian dentists during the spread of contagion. BMC Oral Health. 2020;20(1):200. doi:10.1186/s12903-020-01187-3

18. Zhong BL, Luo W, Li HM, et al. Knowledge, attitudes, and practices towards COVID-19 among Chinese residents during the rapid rise period of the COVID-19 outbreak: a quick online cross-sectional survey. Int J Biol Sci. 2020;16(10):1745-1752. doi:10.7150/ijbs.45221

19. Kamate SK, Sharma S, Thakar S, et al. Assessing knowledge, attitudes and practices of dental practitioners regarding the COVID-19 pandemic: a multinational study. Dent Med Probl. 2020;57(1):11-17. doi:10.17219/dmp/119743

20. Kinariwala N, Samaranayake LP, Perera I, Patel Z. Concerns and fears of Indian dentists on professional practice during the coronavirus disease 2019 (COVID-19) pandemic. Oral Dis. 2021;27:730732. doi:10.1111/odi.13459

21. Namineni S, Mallineni SK. Practice of nitrous oxide inhalation sedation in dentistry during and after the COVID-19 pandemic. J Dent Anesth Pain Med. 2020;20:261-262. doi:10.17245/jdapm.2020.20.4.261

22. Mallineni SK, Bhumireddy JC, Nuvvula S. Dentistry for children during and post COVID-19 pandemic outbreak. Child Youth Serv Rev. 2021;120:105734. doi:10.1016/j.childyouth.2020.105734

23. Sarfaraz S, Shabbir J, Mudasser MA, et al. Knowledge and attitude of dental practitioners related to disinfection during the COVID-19 pandemic. Healthcare (Basel). 2020;8(3):E232. doi:10.3390/ healthcare 8030232

24. Meng L, Hua F, Bian Z. Coronavirus disease 2019 (COVID- 19): emerging and future challenges for dental and oral medicine. J Dent Res. 2020;99:481-487. doi:10.1177/0022034520914246

25. Verbeek JH, Rajamaki B, Ijaz S. Personal protective equipment for preventing highly infectious diseases due to exposure to contaminated body fluids in healthcare staff. Cochrane Database Syst Rev. 2020;4(4):CD011621.

26. Tucho GT, Kumsa DM. Universal use of face masks and related challenges during COVID-19 in developing countries. Risk Manag Healthc Policy. 2021;14:511-517. doi:10.2147/RMHP.S298687

27. Bakaeen LG, Masri R, AlTarawneh S, et al. Dentists' knowledge, attitudes, and professional behavior toward the COVID-19 pandemic: a multisite survey of dentists' perspectives. $J$ Am Dent Assoc. 2020;152:16-24.
28. Alemu T, Amare S, Legesse S, Abera A, Ayalew M, Bezabih B. COVID-19 Knowledge, attitude, practices and their associated factors among Dessie city residents, northeast Ethiopia: a cross-sectional study. Risk Manag Healthc Policy. 2021;14:439-451. doi:10.2147/ RMHP.S287600

29. Bennardo F, Buffon C, Fortunato L, Giudice A. Are dental students aware of and knowledgeable about COVID-19? A Questionnairebased investigation. Open Dent J. 2020;14:623-630. doi:10.2174/ 1874210602014010623

30. Sezgin GP, Şirinoğlu Çapan B. Assessment of dentists' awareness and knowledge levels on the Novel Coronavirus (COVID-19). Braz Oral Res. 2020;34:1-12. doi:10.1590/1807-3107bor-2020.vol34.0112

31. Kochlamazashvili M, Kamkamidze G, McNutt LA, DeHovitz J, Chubinishvili OBM. Knowledge, attitudes and practice survey on blood-borne diseases among dental health care workers in Georgia. J Infect Dev Ctr. 2018;12(10):864-870. doi:10.3855/jidc.9911

32. Rabbani U, Al Saigul AM. Knowledge, attitude and practices of health care workers about Coronavirus disease 2019 in Saudi Arabia. J Epidemiol Glob Health. 2020;11:60. doi:10.2991/jegh. k.200819.002

33. Al Jasser R, Al Sarhan M, Al Otaibi D, Al Oraini S. Awareness toward COVID-19 precautions among different levels of dental students in King Saud university, Riyadh, Saudi Arabia. $J$ Multidiscip Healthc. 2020;29(13):1317-1324. doi:10.2147/JMDH. S267956

34. Arora S, Saquib SA, Attar N, et al. Evaluation of knowledge and preparedness among indian dentists during the current COVID-19 pandemic: a cross-sectional study. $J$ Multidiscip Healthc. 2020;13:841-854. doi:10.2147/JMDH.S268891

35. Bennardo F, Buffone C, Fortunato L, Giudice A. COVID-19 is a challenge for dental education-A commentary. Eur J Dent Educ. 2020;24(4):822-824. doi:10.1111/eje.12555

36. Ammar N, Aly NM, Folayan MO, et al. Knowledge of dental academics about the COVID-19 pandemic: a multi-country online survey. BMC Med Educ. 2020;20(1):399. doi:10.1186/s12909-02002308-w
Risk Management and Healthcare Policy

\section{Publish your work in this journal}

Risk Management and Healthcare Policy is an international, peerreviewed, open access journal focusing on all aspects of public health, policy, and preventative measures to promote good health and improve morbidity and mortality in the population. The journal welcomes submitted papers covering original research, basic science, clinical \& epidemiological studies, reviews and evaluations, guidelines, expert opinion and commentary, case reports and extended reports. The manuscript management system is completely online and includes a very quick and fair peer-review system, which is all easy to use. Visit http://www.dovepress.com/testimonials.php to read real quotes from published authors. 